JURNAL SENI MUSIK

\title{
CREATIVE PROCESS OF EXTRACURRICULAR NASHEED AL- MULTAZAM INTEGRATED BOARDING HIGH SCHOOL IN KUNINGAN BARAT JAWA BARAT
}

\author{
Agam Herlambang ${ }^{\bowtie}$ \\ Suharto \\ Bagus Susetyo
}

Departement of Dance, Drama and Music Universitas Negeri Semarang

\section{Article}

Information

Article History

Received January 2020

Approved February 2020

Published June 2020

Keyword

Creative process,

Extraculicular Nasyid, Creation

\begin{abstract}
Abstrak
Siswa ektrakulikuler nasyid SMAIT Al-Multazam merupakan siswa yang kurang pengalaman bermusik namun menghasilkan kemampuan musikal untuk menciptakan karya nasyid. Tujuan pada penelitian ini adalah untuk mengetahui dan mendeskripsikan bagaimana proses kreatif siswa ekstrakulikuler nasyid dalam menciptakan karya nasyid. Penelitian ini menggunakan pendekatan deskriptif kualitatif. Teknik pengumpulan data yang dilakukan adalah wawancara, observasi, dan studi dokumen. Hasil penelitian ini proses kreatif yang dilakukan oleh siswa ekstrakulikuler nasyid meliputi 4 tahap, yaitu menentukan ide, proses penciptaan lirik nasyid, menentukan akord pada lirik lagu nasyid, metode mengkomposisikan akord pada lagu nasyid dan terciptanya sebuah karya nasyid. Kesimpulannya adalah siswa ekstrakulikuler nasyid masih tahap belajar namun memilih untuk menekuni sampai menciptakan karya nasyid sehingga memiliki suatu proses kreatif untuk menciptakan karya nasyid yang dapat menghasilkan sebuah karya.

Abstract

Nasyid extracurricular students at SMAIT Al-Multazam are students with a lack of musical experience but produce musical abilities to create nasyid works. The aim of this research is to find out and describe how the creative process of nasyid extracurricular students in creating nasyid works. This research use desciptive qualitative approach. Data collection techniques used were interviews, observation, and study of documents. The results of this study the creative process carried out by nasyid extracurricular students includes 4 stages, namely determining ideas, the process of creating nasyid lyrics, determining the chords in nasyid song lyrics, the method of composing chords on nasyid songs and the creation of a nasyid work. The conclusion is that the Nasyid extracurricular students are still in the learning stage but choose to pursue it to create a nasyid work so that it has a creative process to create nasyid works that can produce a work.
\end{abstract}

(C) 2020 Universitas Negeri Semarang

$\bowtie$ Departement of Dance, Drama and Music UNNES, Gunungpati

ISSN 2503-2585 Semarang, Indonesia

Email: suharto@mail.unnes.ac.id 


\section{INTRODUCING}

Art is the result of beauty that is created in the human psyche, distributed through the intermediaries of the human senses. One of the art that can be heard is the art that using sound as part of the art of music also tools for the media to express human expression, both with single instruments such as piano instruments, vocal and guitar. The art of music that is received through the sense of hearing which only relies on beauty in sound is the sound of art. This sound of art contains its own rhythm and harmonization as part of the art of music. As stated by Jamalus (1988, p. 1), music is a work of sound art in the form of songs or musical compositions, which express the thoughts and feelings of the creator through the elements of music, namely rhythm, melody, harmony, song structure / structure, and expressions as a whole.

Songs or musical compositions are works of art if they are played using sound (singing) or with musical instruments. From many branches of music in Indonesia, there are musical arts that are influenced by Islam. In Islam, art is a driving force of reason that can reach further what is behind the material. Every human being has the right to unleash their creativity such as art in reading the AlQuran, the art of calligraphy and others. Islamic art is the expression of a human being about the beauty of being in terms of the Islamic view of nature, life and humans which leads to the perfect meeting of truth and beauty.

In terms, art is something delicate and beautiful and pleases the human heart and feelings. The Islamic Ummah also uses music as a medium of information about Islamic teachings which is packaged in the form of songs known as nasheed or qasidah, and later also develops pop songs with a religious nuance (Wildan, 2007). According to Hutomo (2013), nasyid in Indonesia can now be witnessed in a variety of styles or delivery styles, including (1) Nasyid delivered with acapella which is rhythmic in pop following the music trend that is gaining in popularity. (2) Nasyid performed with acapella and minimalist music (percussion music only) and rhythmic mars, with a spirit of excitement and excitement. (3) Nasyid performed with percussion and pop rhythmic music. (4) Nasyid performed with complete musical instruments.

Nasyid or anasyid (plural) means reading or chanting. Ansyadahu asy-syira means he recites poetry to someone. Munsyid means the person who reads his poem to someone. Poetry reading is an activity that has long been carried out by humans (Muhammad, 2009).

Nasheed is the art of song or song which is likened to a desert song or Arabic music. The song contains religious teachings and social problems that often occur in people's lives. At first the Nasheed was limited to the sound, but then he began to be accompanied by musical instruments that were popular at that time, such as tambourines, large drums, small drums, tambourines and the like (Fikri, 2014).

A munsyid in making nasyid can only be done by someone who understands art, to be able to create nasyid works. Art people are people who try to create pleasant (beautiful) forms, both in the fields of literary arts, music, fine arts, dance and drama. Artists to be able to produce their art works can learn through formal, non-formal and informal education.

Generally a munsyid who studies nasyid art is not a graduate of formal education in music, but can be self-taught, through musical experience, singing experience and not everyone can learn nasyid art.

Formal education is a form of education that has a clear curriculum and clear class levels as well. The curriculum is a learning plan in an educational institution. Non-formal education only has a clear curriculum, but does not have a clear grade level. Informal education does not have both, namely the curriculum is unclear and the level of class is also unclear, for example Salafiyah Islamic Boarding School and education in the family. In the Salafiyah Islamic Boarding School students who have just entered are asked to study together with students who have been there for a long time without a clear learning schedule and clear class levels (Padmowihardjo, 2014).

From the three types of education mentioned above, it turns out that Al-Multazam Islamic High School students who take part in nasyid extracurricular use non-formal and informal forms of education. In terms of informal education, nasyid extracurricular students who intensively share with seniors who already have nasyid song works. In non-formal education, Nasyid extracurricular trainers deliver the material they teached, namely the knowledge of basic tone, harmony and solfegio. If the informal education is usually the upperclassman who already has the songs of nasyid provides knowledge about the history of nasyid development to nasyid extracurricular students. 
To produce nasyid works, nasyid extracurricular students are required to think creatively so that nasyid works to be created can bring up different religious music compositions and new works that have never been known before, one way is creative thinking, creative thinking is a person's thinking to create ideas or new ideas. People who try to think creatively because of a strong desire in their personality to produce something progress, this raises a person's creativity. People who are used to thinking creatively in terms of art will naturally emerge creativity which causes a person to create works of art with the creativity they have.

People who are creative in nasyid art must have had prior musical experience. According to Jamalus (1988, p.2), music experience is the appreciation of a song through listening, singing, playing music, moving to the music and reading music, so students get a thorough understanding of the song's expression. The level of understanding and musical taste of a person is very much determined by the musical experience obtained previously.

The music experience carried out by nasyid extracurricular students at Al-Multazam Islamic High School is starting from listening to songs when before they go to school, nasyid training together in break time during school hours, recovering new songs training and evaluating nasyid training activities previously learned at curfew. With routine practice of nasyid extracurricular students, a musical sense arises in nasheed extracurricular students. The most basic musical taste is rhythm and melody. In singing or playing music we must be able to feel the rhythm of the song and its swing, and be able to imagine the tone and melody of the song in our minds or imagination.

From Jamalus's theory of musical experience that has been explained above one's musical taste can also be awakened by the existence of a musical environment and the musical experience they experienced. Then the question arises whether Al-Multazam Islamic High School students are able to create nasyid works with minimal musical experience. This has made researchers interested in researching the creative process of students at Al-Multazam Integrated Islamic Boarding School in creating nasyid works and this research has never been studied before.

\section{METHOD}

This study aims to identify the creative process of nasyid extracurricular students at Al-
Multazam Integrated Islamic Boarding School in creating his works in Kuningan, West Java. The object of this research is the creative process of nasyid extracurricular students at the Al-Multazam Integrated Islamic Boarding School in creating his works. The data collection techniques using observation, interviews, and study documents. Kenedi (2017), states that observation is the basic method of obtaining data in qualitative research. The purpose of qualitative observation is to understand the subject's behavior as it is. Observations on qualitative research take the form of narratives or descriptions of the things that subjects do during natural conditions. In general, observations are divided into two, namely participant observation and non-participant observation.

The observation in this research is nasyid works created by nasyid extracurricular students. Al-Multazam has different nasyid groups, because every new school year changes a different generation. Nasyid extracurricular students who have created nasyid works in the previous generation, will be continued by the next generation.

This interview was to collect personal data and background of nasyid extracurricular trainers, the creativity process of creating accapella nasyid works and techniques to make acapella accompaniment by nasyid extracurricular students at Al-Multazam High School. Furthermore, knowing the music theory used in the process of creating nasyid works. In addition to these questions, the author will interview supporting speakers who will be submitted to the trainer of nasyid extracurricular students at Al-Multazam High School, who work as nasyid extracurricular teachers. And the Head of Al-Multazam High School as a nasheed extracurricular coach is used to collect and strengthen data about nasheed extracurricular trainers and objectively the process of creating nasyid creative works.

Document is a record of events that have already passed. Documents can be in the form of writings, drawings or monumental works of a person. Data obtained from the study of documents in the form of stored written material. Documents can be in the form of memorabilia or correspondence. There are also documents in the form of audiovisual (Kenedi, 2017). Document Study is a data collection technique on variable matters in the form of notes, transcripts, books, newspapers, magazines, inscriptions, minutes, leggers, agendas, and so on (Ardina, 2012). 
Document study technique is a way of collecting data through written relics, such as archives and including books on opinions, theories, propositions, or laws, and others related to research problems (Eka \& Muttaqin, 2011).

The author uses this technique to obtain data or information in the form of documents, such as scores of students work of nasyid extracurricular, photos and pictures, video and recording audio when doing interviews of nasyid works by students Nasyid extracurricular activities and documentation of other activities conducted by Nasyid extracurricular activities.

Data in the form of photos and videos obtained through documentation from other people or informants who already have documentation before researchers doing research by taking pictures of objects using a mobile camera during nasyid extracurricular exercises. Documentation in the form of photographic images and video images aims to complement the data that has been obtained previously, namely observation and interviews. From all the data that has been collected, then rechecked to obtain more reliable data to provide an overview of the nasyid creativity process within the scope of the Al-Multazam Integrated Islamic Boarding School.

\section{RESULT AND DISCUSSION}

Education is a conscious and planned effort to create a learning atmosphere and learning process so that students actively develop their potential to have religious spiritual strength, selfcontrol, personality, intelligence, noble character, and the necessary skills that useful to themselves.
Al-Multazam
Islamic
Education

Foundation Husnul Khotimah organizes formal education levels under the Ministry of National Education namely PAUD (KOBER and TKIT), SDIT, SMPIT and SMAIT. The education system that is implemented uses the Islamic Education System, Integrated and Sustainable also known as Education System of Boarding School, where students are required to live in a dormitory and participate in all educational programs. For students who have completed the program at the SMPIT level and then continue the SMAIT level.

Al-Multazam High School is a favorite and suitable for students who want to seek knowledge in education while learning about the religion of Islam. Al-Multazam High School is known by the surrounding community in Kuningan with a lot of achievements in the academic and non-academic fields. One of them is non-academic achievement, namely nasheed extracurricular.
In the creative process to create a nasheed work, collaboration between students and Kang Cahyo as nasheed extracurricular trainer was carried out in evaluating the creation of nasheed lyrics, the process of making nasheed songs to the packaging of Al-Multazam's first nasyid album and Kang Fajar Perdana as arranger in the song recording process. In the album there are 15 nasheed works by nasheed extracurricular students with 5 teams.

Nasheed work is divided into 2 parts, the first part is the Ikhwan team which consists of 3 team, the second part of the Akhwat team which consists of 2, the Ikhwanteam namely El-Zukhruf team with 2 works, namely Air (Aku Ingin Your Ridho) and Api (Aku Peduli Indonesia). The Khalafah nasyid team with 5 works, namely Tanah (Cerita Nenek Dahulu), Sahabat, Udara (Muda Berkarya), Sungai (Syukuri Anugerah Ilahi), Hasbunallah. Nabacapella team with 1 nasheed work, namely Kisah 3 Hamba, then Akhwat team namely Shouttunnada team (Gen.1) with 2 works, namely Perjalanan Baru and Kisah Kita, then Shouttunnada team (Gen.3) with 1 work namely Sumayah Binti Khayyat. The author examines one of the nasyid songs from the Ikhwan team namely Khilafah team listed on Al-Multazam's nasheed album "Hasbunallah", because the lyrics of this song were created by team itself to find out how the students created the nasheed work.

In the process of creating nasyid works there needs to be preparation, this preparation is the beginning of the creative process in creating nasyid works. The author will relate the concept of the creative process described by Piirto, 1992 (in Munandar, 2002, p. 59) by citing the theory put forward by Wallas (1926) in his book "The Art of Thought" which states that the creative process includes four stages, namely (1) preparation, (2) incubation, (3) illumination, and (4) verification.

\section{The Creative Process of Nasyid Extracurricular Students in Creating Their Works}

\section{Step of Determining Ideas}

The creative process carried out by nasyid extracurricular students in creating their work have 5 stages. The initial stage of creating nasyid works is determining the basic ideas. In this stage students must create nasyid songs with religious characters accapella and in accordance with the age of youth in high school. Nasyid lyrics that will be created explain how the contents of the song, the message to be delivered, and the meaning contained in the song must be in accordance 
with the age of youthful high school, meaning that the stage is not sideways from the religious path. By participating in nasyid extracurricular activities, students gain musical experience, starting from listening to Islamic songs, practicing tone sensitivity, often practicing during leisure time, and processing vocal techniques, so that when performing on the stage or competing in certain events, mentality and voice the nasyid team from other schools in practicing nasyid is not as much as the nasyid team from the Al-Multazam Integrated Islamic Boarding School. If you have gained musical experience, then a musical sense arises by itself in someone personal self.

One example of the application of the creative process in the stage of determining the basic ideas in the work of the Nasyid Khilafah Team can be seen through the song "Hasbunallah". The basic idea of this song was obtained when the Nasyid Khilafah Team competed a contest in the Khusnul Khotimah Kuningan Islamic Boarding School in West Java. Then there is a nasyid team from other schools before presenting a compulsory song when competing, the delivery method at the opening with Hasbunallah lyrics, according to the nasyid team the Khilafah considers the opening method to be beautiful, then the Khilafah nasyid team plans to develop the lyrics into a song with a standard benchmark from the nasyid team another school.

The word Hasbunallah has the meaning "Cukuplah Allah or Enough Allah", where the message contained in the lyrics of this song tells the form of devotion, the form of resignation someone surrendered fully to Allah. With this sentence, we surrender all soul, body, and all matters, burdens, problems in the world to Allah. This basic idea was obtained spontaneously, and was not planned by the Khilafah nasyid team. The first thing done by nasyid extracurricular students is to determine the basic ideas of what they experience from their experiences and look for messages and the meaning of songs to be created.

\section{Step of Creation of Nasyid Lyrics}

After determining the basic ideas on the nasyid song that will be created, then determine the lyrics to the song through a message from the song title. The basic idea of this song was obtained when the Nasyid Khilafah Team competed a contest in the Khusnul Khotimah Kuningan Islamic Boarding School in West
Java. Then there is a nasyid team from other schools before presenting a compulsory song when competing, the delivery method at the opening with Hasbunallah lyrics, according to the nasyid team the Khilafah considers the opening method to be beautiful, then the Khilafah nasyid team plans to develop the lyrics into a song with a standard benchmark from the nasyid team another school. Then the title of the song Hasbunallah was developed to contain a message where the lyrics of this song tell the form of devotion, the form of resignation of a servant surrendered fully to Allah.

With this sentence, a servant surrenders all his soul, body, and all matters, burdens, problems in the world to Allah. The process of creating the lyrics of the song "Hasbunallah" includes 2 weeks, carried out in a comfortable and quiet place such as Ba'da Isha prayer at Al-Multazam Mosque and in the santri room by the Khilafah nasyid team. The process of creating nasyid song lyrics was created by the Khilafah nasyid team itself. In accordance with the meaning of the title Nasyid Khilafah team composed the lyrics below:

Intro

Hasbunallah wanikwal wakil nikmal maula wanikman nasir Musibah itu hikmah

Chorus 1

Dunia hanyalah sementara

Jangan kita terlena, hingga kita lupakan kepada

Chorus 2

Allah memberikan ujian kepada manusia

Siapa yang paling bertaqwa diantara kita?

Brige

Jangan pernah berputus asa, yakinlah kita bisa, melewatinya

Reff

Hasbunallah wanikwal wakil nikmal maula wanikman nasir

Musibah itu hikmah

Hasbunallah wanikwal wakil nikmal maula wanikman nasir

Bersabar dan Tawakal

Chorus 2

Allah memberikan ujian kepada manusia Siapa yang paling bertaqwa diantara kita? 
Brige

Jangan pernah berputus asa, yakinlah kita bisa, melewatinya

Reff

Hasbunallah wanikwal wakil nikmal maula wanikman nasir

Musibah itu Hikmah

Hasbunallah wanikwal wakil nikmal maula

wanikman nasir

Bersabar dan Tawakal

Hasbunallah wanikwal wakil nikmal maula

wanikman nasir

Musibah itu Hikmah

Hasbunallah wanikwal wakil nikmal maula

wanikman nasir

Bersabar dan Tawakal

Hasbunallah

\section{Step of Determining the Chords on Nasyid Song Lyrics}

How to determine the chords for the song Hasbunallah takes from the implementation of the lyrics "Hasbunallah". At the beginning of the song "Hasbunallah" the first chord uses the primary chord namely Dominant. Below this is the Melodic intro part of the Nasyid Khilafah Team.

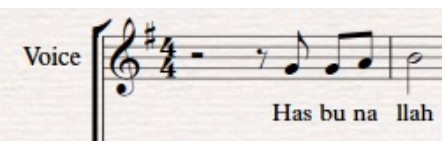

Then proceed in the form of chords, adjust to the next melody that has been created by the Khilafah nasyid team, so it becomes like the following sample below.
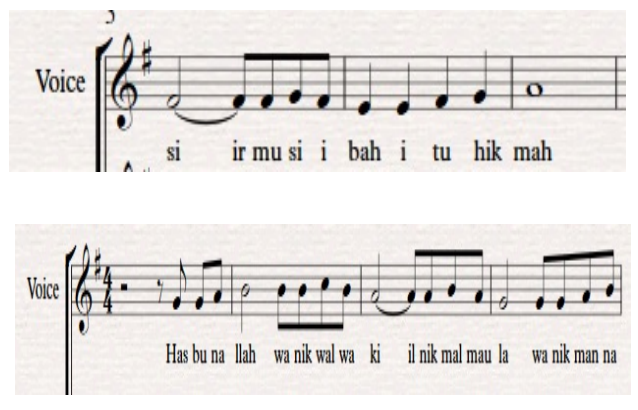

The lyrics of "has-bun-allah" with the sol-sol-lasi melodic ending with the "si" tone using the $G$ chord, following lyrics of "wa-nik-wal-wa-kil" with the melodic si-si-do-si-la ends with the tone "la" uses the D chord, the lyrics "nik-malmau-la" have the melodic la-si-la-sol ending in the "fi" chord using the Em chord, the lyrics "wa-nik-man-na-sir" with melodic sol-sol-la-sifi using the D chord, the lyrics "mu-si-i-bah" with melodic fi-sol-fi-mi using $\mathrm{C}$ chord and the lyrics" itu-berkah" with melodic mi-fi-sol-la uses the D chord.

Then proceed after the lyrics intro to the intro with vocals and so on. After completing the chords in the song lyrics, the nasyid extracurricular ex-trainer and the nasyid extracurricular trainer participated in evaluating what the Khilafah nasyid team had done.

\section{Step of Method of Composing Chords on a Nasyid Song}

In the song "Hasbunallah" created by the Khilafah nasyid team, the intro part of the song contained the chords G, D, Em, D, C, D. Then from each chord was broken into 3 parts, when it was broken into 3 parts, then look for the nearest tone. For example, Chord G consists of Sol-Si-Re to D chords consisting of Re-fi-La tones, then the closest notes are Sol to $\mathrm{La}$, Si to $\mathrm{Fi}$, and Re to Re. Each of the 3 notes that have been divided is then sounded to the nasyid team personnel themselves. Next is the composition of the $\mathrm{G}$ to $\mathrm{D}$ chord which has been broken into 3 parts, namely the sound of Alto, Tenor Bariton.

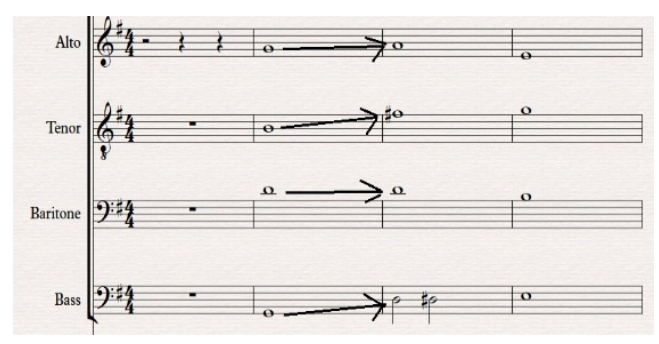

When it has been distributed to 3 personnel to do the right harmony, then look for the closest note from one chord to another. With tones on the voice 1 (Alto) that has been used, may not be used again and continued to tones that has not been used voice 2 (Tenor) and voice 3 (Baritone). After the tone has been sung each vocalist, then lead vocal as the main vocalist 
has sung it as a benchmark of harmony personnel. Voice 1 (Alto), 2 (Tenor), 3 (Bariton) sing the tone which later becomes the chord forming of the song Hasbunallah. Sound 4 on song Hasbunallah became bass which was enough to sweeten the song, after that it continued to look for the closest and most perfect tone.

\section{Step of Creation of a Nasyid Work}

The last step is the creation of a nasyid work as a form of a creative product. At this step, a nasyid work has been created and can be tested against the nasyid's work to ensure and see the whole work. After the song lyrics are created, determine the chords in the song lyrics and compose the chords in the song lyrics, the next process is the process of recording song. To obtain the accapella nasyid song recording process, an arranger is need to create a nasyid acapella song, on the song "Hasbunallah" at that time called on personnel from Pizzicato Acapella's nasyid group named Kang Fajar Perdana to assist the recording process of the Khilafah nasyid song. The recording process is carried out directly at the Al-Multazam Integrated Islamic Boarding School, the recording uses Cubase software.

The first step in the recording process of the Khilafah's nasyid team was testing the work he had created, the first testing was conducted with the Harmoni voice nasyid personnel team, namely alto, tenor and baritone, to check the solmisasi (Solfeggio) of each Khilafah nasyid team personnel using the Cubase software repeatedly. This is done to ensure the tone of the song that is sung is right and there is no fals of any part of the song he created.

Then for the second test conducted by the Khilafah nasyid team starting from vocall, vocal2, alto, tenor, baritone, bass, and beatbox sing his work directly to see in full how the work he has created. If after testing each personnel has sounded as expected, then the nasyid song works are ready for the recording process, but if there are any errors in certain parts, the nasyid extracurricular trainer will immediately correct the sound of what tone that students expected.

To get perfect results, the process of recording the song "Hasbunallah" took about 2 days, the first process to start recording is to prepare the recording tools according to their respective places. After that, start recording the intro by vocal1, tenor, alto, baritone, and bass, then vocal2 and beatbox followed. The second process is to adjust what has been recorded starting from after the intro to verse, song1, song 2 , bridge and refrain, to song2, refrain, and repeated twice then until the end of the song. If it has been recorded, the arranger will bring the recordings to the mixing step, after the mixing has been done, will be given to the nasyid extracurricular trainer. Then with the approval of the Khilafah nasyid team and nasyid extracurricular trainers, the work of the Khilafah nasyid team titled "Hasbunallah" has done.

\section{Form / Structure and Texture of Hasbunallah Song}

According to Karl (2004, p.2), song form / structure is an idea / idea that appears in the processing / arrangement of all musical elements in a composition (melody, rhythm, harmony, and dynamics). The basis for the formation of this song includes the repetition of a part (repetition), repetition with various changes (variasai / sequences), or the addition of new parts that are different or opposite (contrast). Two or more song sentences form one part of the song.

There are simple songs that have the form of one part usually repeated. The form of the onepiece song that is repeated is called AA. One example in the form of a one-part song that is a simple binary form, is a song form consisting of two forms of a part, this binary form is called A B. This binary form can be extended by repeating the parts so that it becomes $\mathrm{AAB}, \mathrm{ABB}$, or AABB (Jatmiko, 2015).

Song form according to the number of sentences then divided into 3 types, namely the form of one part song with only one sentence, twopart song form with two different sentences and three-part song form with three different sentence forms. Hasbunallah is a nasyid work from the Khilafah group which has a simple song form, that means the song works as usual. The form of the Hasbunallah song in theory has been explained in the form of three parts, because it has more than 32 bars which have an intro, verse, song1, song2, bridge and refrain so it can be concluded that the song form of Hasbunnallah is A (ax), B (by), CC 'because this type of song in every question and 
answer brings new motives like in the first intro, verse and song and brige.

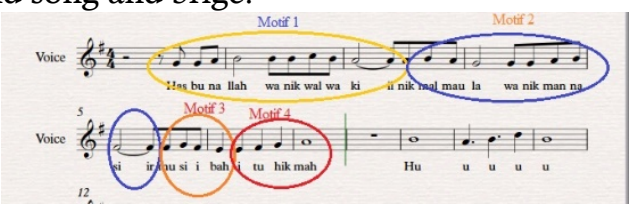

Motive in the Hasbunallah intro

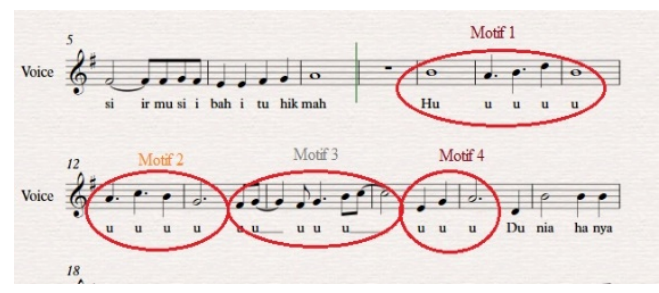

\section{Motive in verse}

Hasbunallah is nasyid's work from the Khilafah group, the song form of Hasbunnallah namely A (ax), B (by), CC'. Hasbunallah has a characteristic that can be seen from the end of the sentence at the end of each phrase, where the last phrase uses the rhyme pattern a-a-a-a. According to Hamidin (2016) in the journal Language (Language and Literature) Halu Oleo University, said that in the form of poetry there is a physical structure of poetry which consists of typography, diction, images, style of language, concrete words, and rhymes or rhythms. Broken rhyme / poem, which is the sound equation that is arranged erratically at the end of the lines of poetry (a-b-c-d).

Based on the type of rhyme (taxation) can be divided into 7 types, namely imperfect rhyme, the sound equation in the last syllables. Imperfect rhymes, which are the sound phrases found in some of the last syllables. Absolute rhyme, which is the sound equation that is contained in two or more words absolutely (syllable syllables). Open rhyme, which is the sound equation found in the final syllable open or with the same vowel. Closed rhymes, namely the sound equalization of closed syllables (consonants). Alliteration rhymes, namely the sound equation found in the initial sound of words in the same line or different lines. Asonance rhyme, the sound equation found in the middle vowel asonance of the word and the rhyme of consonance, that is the sound equation found in dead letters / consonants.

The song form in Hasbunallah uses the type of open rhyme, which is the sound equation found in the final open tribe or with the same vowel, the part of the open rhyme lies in the 16th to 35 th century with the beginning of the lyrics " Dunia hanyalah sementara" to the end of the lyrics "Siapa yang bertaqwa diantara kita". The rhymes types and patterns as explained are deliberately created by nasyid extracurricular students to beautify the lyrics of the song.

In addition to the rhymes in the lyrics of the song Habunallah which make Hasbunallah unique, chords and melodies also help determine the beauty of the rhyming patterns of Hasbunallah. In order to sound beautiful, nasyid extracurricular students create the end of the Hasbunallah song with Chord 1 or G. How to see the shape or structure of the song from Hasbunallah, the beauty can be seen from the melody created, then the chords made at the end of the phrase by forming a rhyme aa-a-a pattern. Next is the Hasbunallah song from the beginning of the intro to the end of the song with the final form of a phrase that has been changed into chords and a-a-a-a rhythm patterns.

\section{Chorus 1 \\ Dunia hanyalah sementar(a) \\ Jangan kita terlen(a), \\ hingga kita lupakan kepad(a)}

\section{Chorus 2 \\ Allah memberikan ujian kepada manusi(a) \\ Siapa yang paling bertaqwa diantara kit(a)?}

In the course of the melody will be found song motifs, song phrases, and song sentences. In each part of the Hasbunallah song form there are forms of motifs, phrases and sentences. To facilitate our understanding, the structure of this music can be compared with the structure of language that we are familiar with. Letters $=$ not, Words $=$ motives, Phrases $=$ phrases, Sentences $=$ musical sentences (Jamalus 1988, p. 35).

In a sentence consisting of 4 bars has 2 motives and every 2 motive has a question phrase and answer phrase. Because the phrase is a series of several song motives. The following is the form of 
phrases in the intro, verse, song1, song2, bridge and refrain sections of Hasbunallah.

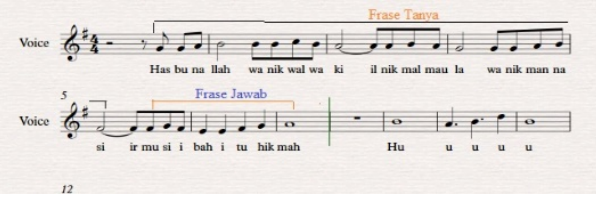

Phrase in the intro of Hasbunallah

$$
\begin{aligned}
& \text { voke } b^{3}, \ldots \ldots \ldots \ldots \ldots
\end{aligned}
$$

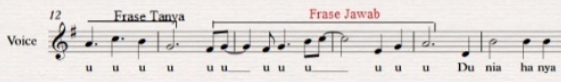

$$
\begin{aligned}
& 18 .
\end{aligned}
$$

Phrase in the verse of Hasbunallah

Texture is a form of network combining the elements of melody and harmony that produces heavy and light, thick or thin sound quality (Jamalus, 1988, p. 33).

Monophony according to Banoe (2003, p. 281) said, monophony is a single voice. Music works in the form of melodies without the support of harmony or other sound that is counterproductive. Poliphony is music that is composed "horizontally" and (vertically) wherein, so that each sound is independent of instinct (instinct) individually (not together) the sound of the one chased with the sound that starts afterwards while imitating but with uasaha anyway so that joint sounds produce consonant or dissonant intervals (Karl, 2004, p. 102). Homophony is the form of a melody line supported by accompaniment or acompanyment by using chords or other forms (Jamalus, 1988, p. 33).

Hasbunallah is included in the texture of polyphony because in the song there are chords that are divided into three parts of the sound, by having the main melody and secondary melody. In other melodies as accompaniment the main melody is included in the homophony texture because the other melodies support the main melody. A melody that supports the main melody in the bass, baritone, alto, tenor parts.

\section{Hasbunallah song rhythm}

According to Jamalus (1988, pp. 7-8), rhythm is a sequence of movements that form the basic elements in music and dance. The rhythm in music is formed from a group of sounds and is silent with various lengths or lengths, forming rhythmic patterns, moving according to pulses in a time swing.

Nasyid's work with the title Hasbunallah is written with bars or beats $4 / 4$ which means that in one bar there are 4 beats with each note value $1 / 4$. Accents fall on every first bar. In Hasbunallah, the accent was seen from the beginning of the song. In the first part of the song, the main melody, vocal one and vocal two, plays with the same rhythm, and the sounds of alto, tenor, baritone and bass are also played with the same rhythm. Hasbunallah uses beatbox for rhythmic instruments instead of drum. Beatbox is an rhythmic instrument that has a basic rhythmic pattern and a pattern of development. The following rhythm on the beat one to four.

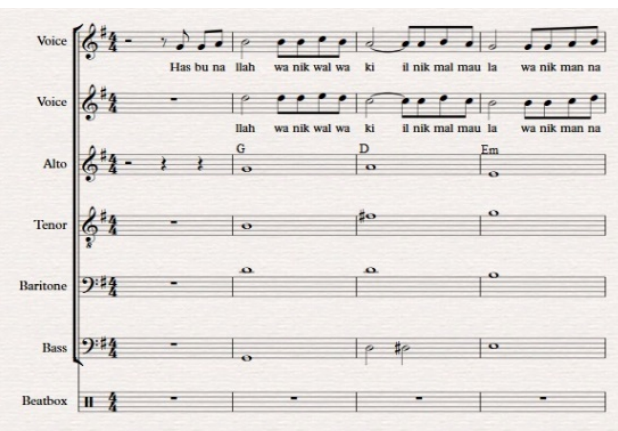

In Hasbunallah music sheet music that has a consistent rhythm, the sound of the alto tenor baritone and the bass for the rhythm of the beatbox has a lot of development from the main rhythm like in the intro rhythmic $8-15$ is the main rhythm or rhythm. Beatbox is an art form that imitates the rhythm, drum pattern, musical instruments, or imitations of sounds so that the beatbox can support the instruments in Accapella music. For beat rhythm patterns like the following sample:

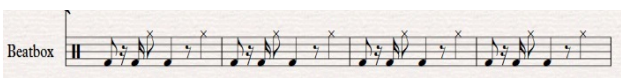

The beatbox rhythm pattern in the verse with the main rhythm.

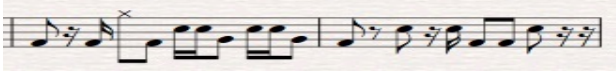

Beatbox beat rhythm pattern intro to song 1

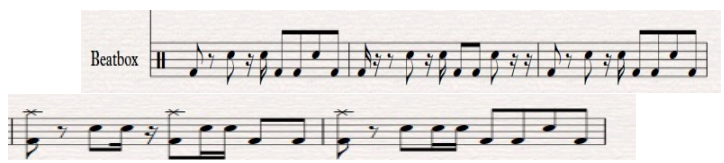

Development of beatbox beat patterns on Bridge 


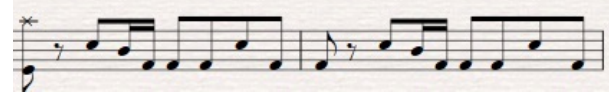

Beatbox patterns on Bridge refrain

\section{Hasbunallah song melody}

Melody is the second element of music after rhythm. Singing people always produce melodies that are the concern of music lovers. With the capital of knowledge, appreciation, skills and creativity of music artists can create various songs (Ratmiatin, 2018).

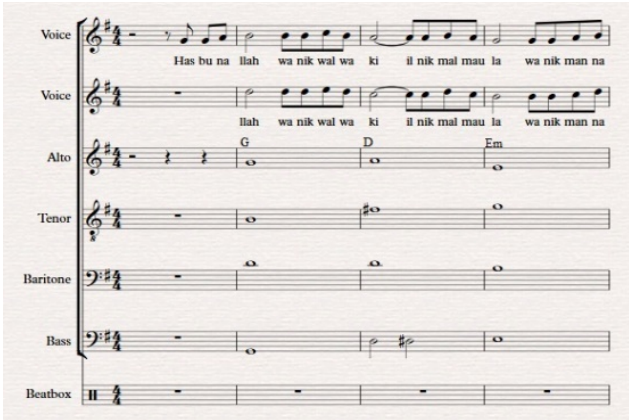

Hasbunallah's music sheet shows using the G scale. In a nasyid work with the title Hasbunallah the melody uses the key $G=$ Do in Major (G).

There are some melodic movements including horizontal, stepping, and jumping. Horizontal melody movement is a melody movement that has the same notes. A stepping melody is a moving melody that changes but the movement is not too drastic, for example in a melody do to $\mathrm{mi}$, or sol to si. While jumping melodies are melodies that have a high-pitched tone movement, for example from sol to re and so on. In the song Hasbunallah partiture as a whole the melody movement is stepping up and down, but there are some songs that have a jumping melody. Upward stepping melody is in the 34th rhythm, the stepping down is in the 24th rhythm and the jumping melody movement is in the 41 st.

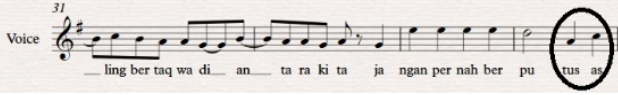

The melody stepping up

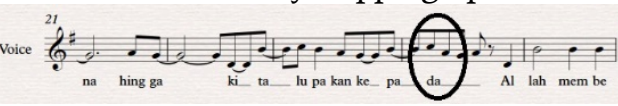

The melody stepping down

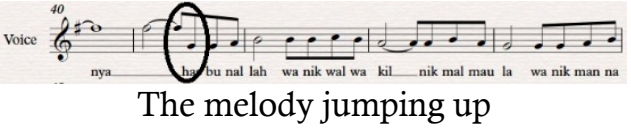

The highest pitch in Hasbunallah song that can be seen in the vocal melody is $F \# 5$ on the $G$ major scale and the lowest pitch is D4, what is meant by the pitch is the region (ambitus) between the lowest pitch and the highest pitch in one song composition. Hasbunallah includes the use of vast tunes.

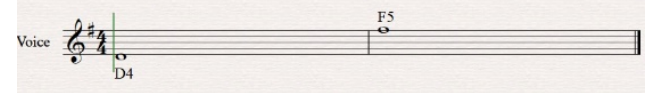

The lowest and highest tone

4. Hasbunallah song harmony

Harmony or chord is the sound of a combination of two or more tones, which differ in height and we hear simultaneously, the basis of this chord is trinada. (Jamalus, 1988, p. 30).

The harmony used in the Hasbunallah song has a simple harmony with less complicated chord movements. Chords according to the concept of harmony played from the Hasbunallah song, namely using primary and secondary chords where the primary chords consist of chords I, IV, V and secondary chords vi, II, iii, vii. The chords on the Hasbunallah song are as follows below.

At the beginning or intro has a chord I - V - vi - V IV - V next to the part before entering the song or verse has a chord I - V - vi - V - IV - I - IV - V, the song has the chord I - V - vi - V - IV - I - IV - V, then enter the bridge before entering the refrain has an IV - V - I - vi - IV - V - IV - V chord, the refrain section is the same as the intro chord at the beginning. In the Hasbunallah song it has pure perfect cadenza which is a form of cadenza whose chords are in the basic position for example on the bass part as the lowest note whose role is to be occupied by the chord base tone.

In harmony there is also a part of the canon, the discant, the drone and the ostinato. Canon is song with a harmonic network in the form of imitation. Discant is the second melody that is usually added above the original melody. The drone is the long bass sound as the accompaniment. Ostinato are repetitive sound patterns. This understanding is found in the Hasbunallah song except in the ostinato section as follows:

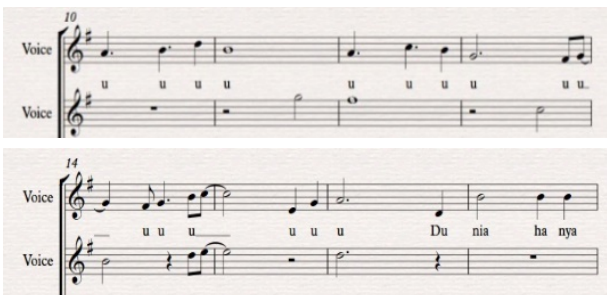


A song melody that has a canonical or nested part

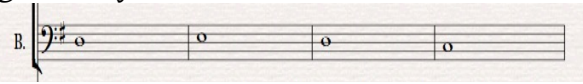

The melody part that has a drone

Besides having a canon, discant and drone section, the Hasbunallah song has a section that contains modulation or transposition. As stated in the theory of Jamalus (1988, p. 33), Modulation is the process of moving a scale to another scale in a song. Basically modulation can occur either to the Major scale or to the minor scale. The more the same notes or allied tones in the scales used. Transposition is the transfer of the scale in playing, singing, or writing a song from the original scale, but the song remains the same.

Hasbunallah has a meaningful modulation or transposition section the central root or (Tonika) is replaced with a new central chord or (new Tonika). In other words, change the basic tone of the song. Modulation in the Hasbunallah song comes from the basic note $G=$ Do to $A=$ Do or 1 \# (one sharp) to 3 \# (three sharp).

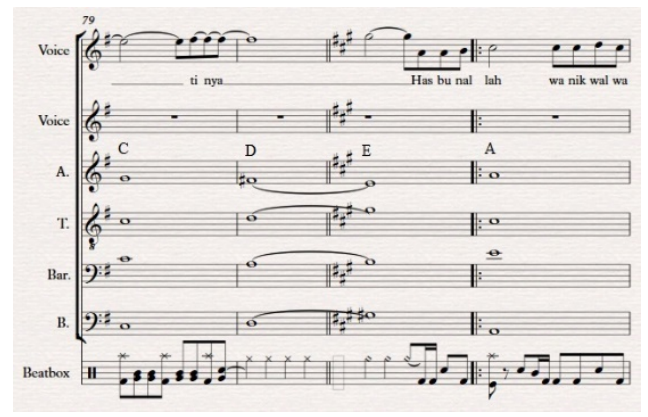

The modulation part

\section{CONCLUSION}

Based on the results, the form of creativity possessed by someone can be seen from four aspects, namely (1) creative personality, (2) factors driving creativity, (3) creative process, and (4) creative products. In this study, the creativity of nasyid extracurricular students in creating nasyid works can be seen from these four aspects, as well as from the analysis of the Hasbunallah song. The creative process of the creation of the work goes through various stages so that even though Nasyid extracurricular students at Al-Multazam High School have no background in music experience, the nasyid team can play music and create nasyid works and can be accepted in the wider community in Kuningan and its surroundings are part of musical creativity.

\section{REFERENCES}

Ardina, M. D. (2012). Implementasi Pembelajaran Musik Untuk Mengembangkan Mental dan Psikomotorik Anak Penderita Down Syndrom. Harmonia: Jurnal Pengetahuan Dan Pemikiran Seni, 12(2), 125-131.

Eka, B., \& Muttaqin, M. (2011). Pembelajaran Biola dengan Metode Suzuki pada Anak Usia Dini. Universitas Negeri Semarang, (1), 11. Retrieved from

http://journal.unnes.ac.id/nju/index.php/harmon ia/article/download/63/3822

Fikri, S. (2014). Seni Musik dalam Perspektif Islam. Studi Multidisipliner, Volume 1(2), 25.

Hutomo, M. P. (2013). Karakteristik Musik Nasyid "Nada Hati." Universitas Negeri Yogyakarta.

Jamalus. (1988). Pengajaran Musik melalui Pengalaman Musik. Jakarta: Direktorat Jenderal Pendidikan Tinggi Departemen Pendidikan dan Kebudayaan.

Kenedi. (2017). Pengembangan Kreativitas Siswa dalam Proses Pembelajaran di Kelas II Smp Nergeri 3 Rokan IV Koto. Jurnal Ilmu Pendidikan Sosial, Sains, Dan Humaniora, 3(2), 329-348.

Moleong, L. J. (2000). Metode Penelitian Kualitatif. Bandung: PT. Remaja Rosdakarya. Retrieved from

https://www.goodreads.com/book/show/63884

82-metode-penelitian-kualitatif

Muhammad, S. (2009). Peranan Teknik Vokal dalam Persembahan Nasyid Kontemporari di Sekolah. Universiti Pendidikan Sultan Idris.

Padmowihardjo, S. (2014). Pengertian Psikologi Belajar Mengajar dan Definisi Proses Belajar. Retrieved from http://repository.ut.ac.id/4427/1/LUHT4232M1.pdf

Prismanatan, Y., \& Utomo, U. (2015). Musik Angklung sebagai Media Ekspresi bagi Penderita Tunarungu di SLB Negeri Sragen. Jurnal Seni Musik, 4(2), 31-36. 
Sukardi. (2003). Metodologi Penelitian Pendidikan Kompetensi dan Praktiknya (1st ed.). Jakarta: PT Bima Aksara. Retrieved from https://www.tokopedia.com/muqrah/metodolog i-penelitian-pendidikansukardi?c=\%7BcampaignId $\%$ 7D\&m $=\%$ 7Bmer chant_id\%7D\&p=\%7Bproduct_id\%7D\&ev_efi $\mathrm{d}=$ CjwKCAjwkcblBRB_EiwAF $\bar{F}$ fyy $18 \mathrm{DTht} \mathrm{V}$ faW8e3hFtsU2uwbjiDp $7 \mathrm{kj}$ 94598oj4YeotKmnYuOx81mBoCRHYQAvD_ BwE:G:s\&ds_rl=1261173\&gclid

Sumaryanto, T. (2007). Pendekatan Kuantitatif dan Kualitatif dalam Penelitian Pendidikan Seni. Retrieved from https://scholar.google.co.id/citations?user=bDbi nBcAAAAJ\&hl=en

Wildan, R. (2007). Seni dalam Perspektif Islam. Islam Futura, VI(2), 78-88. 